\title{
To Study the Various Co-curricular Activities of Girl Student of Kasturba Gandhi Balika Vidyalaya and Government Upper Primary School of East Siang District Arunachal Pradesh
}

\author{
Bombi Riram ${ }^{1 *}$, T. K. Lhungdim ${ }^{2}$ \\ ${ }^{1}$ Assistant Professor, Department of Education, Donyi Polo Government College, Kamki, India \\ ${ }^{2}$ Professor, Department of Education, Rajiv Gandhi University, Itanagar, India \\ *Corresponding author: bompiriram84@gmail.com
}

\begin{abstract}
Co-Curricular Activities are important part of curriculum. These activities are important for the overall development of students. Though CCA are non-academic activities, it supports the academic purpose of schools, through positive reinforcements for the social and emotional aspects. It benefits the school children in gaining valuable academic and social experiences by providing wide range of opportunities and experience for self-expression and participation. The present study is an attempt to study the participation of girls' students in various co-curricular activities that are organised in the Kasturba Gandhi Balika Vidyalaya and Government Upper Primary School of East Siang District of Arunachal Pradesh. A sample of 4 KGBV and 4 GUPS from 2 blocks, 5 teachers and 10 girls' students from each school have been taken by following simple random technique. The total sample consist of 8 schools, 40 teachers and 80 girls' students. It is a descriptive research study. For collecting various information, the researcher used the constructed questionnaire. The data analysis had been done by using simple frequency and percentage technique. The findings of the study revealed that girls' students of KGBV took more active participation in CCA than GUPS.
\end{abstract}

Keywords: Co-curricular activities, Government upper primary school, Kasturba Gandhi Balika Vidyalaya.

\section{Introduction}

Co-Curricular Activities are of immense important for the all-round development of the students. In the traditional curriculum, CCA were known as Extracurricular activities. However, in the modern context these activities are recognised as essential and integral part of the curriculum. It supports the very academic purpose of the schools through providing positive reinforcements for the social and emotional aspects. The students by participating in various CCA learn to be involved in healthy activities that will built up their self confidence and self-esteem. The Education Commission stated that, "we conceive of the school curriculum as the totality of learning experiences that the school provides for the pupils through all the manifold activities, in the school or outside that are carried on under its supervision".

\section{Rationale of the Study}

CCA though have less status in education than the main curriculum, these activities are indispensable and held to be very important in the wider sense of education. The concept of CCA becomes changed. Now-a-days at almost every level of education Co-Curricular Activities becomes an integral part in the main curriculum. The present study is an attempt to study the participation of girls' students in various co-curricular activities that are organised in the Kasturba Gandhi Balika Vidyalaya and Government Upper Primary School of East Siang District of Arunachal Pradesh.

\section{Objectives of the Study}

1) To find out the various Co-Curricular Activities of Kasturba Gandhi Balika Vidyalaya and Government Upper Primary School of the East Siang districts of Arunachal Pradesh.

2) To find out the girls' participation in various Co-Curricular Activities in Kasturba Balika Vidyalaya and Government Upper Primary Schools of East Siang district of Arunachal Pradesh.

\section{Methodology}

Sample of the study:

For the present study the investigator has adopted descriptive survey method and Random sampling technique. The total sample consist of 50 teachers and 50 girls' students from KGBV and 50 teachers and 50 students from GUPS of East Siang district of Arunachal Pradesh. The names of the school taken for the study are presented in the table 1 .

Tools Used:

The investigator used the self-constructed non- standardized questionnaire for collecting the data.

Statistical Analysis of the Data:

Frequency and percentage have been used for the analysis of data objective wise. 
Volume-3, Issue-11, November-2020

https://www.ijresm.com | ISSN (Online): 2581-5792

Table 1

The sample schools selected for the study

\begin{tabular}{|l|l|l|}
\hline S. No. & Names of the school & No. of girl students taken \\
\hline 1 & KGBV Kiyit & 10 \\
\hline 2 & KGBV Mottum & 10 \\
\hline 3 & KGBV Yagrung & 10 \\
\hline 4 & KGBV Pasighat & 10 \\
\hline 5 & KGBV Mirem & 10 \\
\hline 6 & GUPS Namsing & 10 \\
\hline 7 & GUPS Mebo & 10 \\
\hline 8 & GUPS Daying Ering Memorial & 10 \\
\hline 9 & GUPS Pasighat Sawmill & 10 \\
\hline 10 & GUPS JN College campus & 10 \\
\hline Total & 10 Schools & 100 girl students \\
\hline
\end{tabular}

Table 2

Responses made by the girls' students of Kasturba Gandhi Balika Vidyalaya and Government Upper Primary Schools of East Siang district of Arunachal

\begin{tabular}{|c|c|c|c|c|c|}
\hline \\
\hline S. No. & Items & Schools & Options & $\mathrm{f}$ & $\%$ \\
\hline \multirow[t]{4}{*}{1} & \multirow{4}{*}{$\begin{array}{l}\text { Does your school } \\
\text { organise CCA? }\end{array}$} & KGBV & Yes & 50 & 100 \\
\hline & & & No & 0 & 0 \\
\hline & & GUPS & Yes & 50 & 100 \\
\hline & & & No & 0 & 0 \\
\hline \multirow[t]{44}{*}{2.} & \multirow{44}{*}{$\begin{array}{l}\text { Please specify the } \\
\text { activities in which you } \\
\text { have participated by } \\
\text { putting the tick marks } \\
\text { ( ) }\end{array}$} & KGBV & Yes & 38 & 76 \\
\hline & & Athletic & No & 12 & 24 \\
\hline & & \multirow[t]{2}{*}{ Football } & Yes & 30 & 60 \\
\hline & & & No & 20 & 40 \\
\hline & & \multirow[t]{2}{*}{ Volleyball } & Yes & 45 & 90 \\
\hline & & & No & 5 & 10 \\
\hline & & \multirow[t]{2}{*}{ Debate } & Yes & 18 & 36 \\
\hline & & & No & 32 & 64 \\
\hline & & \multirow[t]{2}{*}{ Quiz } & Yes & 28 & 56 \\
\hline & & & No & 22 & 44 \\
\hline & & \multirow{2}{*}{$\begin{array}{l}\text { Extempore } \\
\text { speech }\end{array}$} & Yes & 10 & 20 \\
\hline & & & No & 40 & 80 \\
\hline & & \multirow{2}{*}{$\begin{array}{l}\text { Essay } \\
\text { Writing }\end{array}$} & Yes & 22 & 44 \\
\hline & & & No & 28 & 56 \\
\hline & & \multirow[t]{2}{*}{ Poetry } & Yes & 8 & 16 \\
\hline & & & No & 42 & 84 \\
\hline & & \multirow[t]{2}{*}{ Recitations } & Yes & 31 & 62 \\
\hline & & & No & 19 & 38 \\
\hline & & \multirow[t]{2}{*}{ Singing } & Yes & 36 & 72 \\
\hline & & & No & 14 & 28 \\
\hline & & \multirow[t]{2}{*}{ Dancing } & Yes & 42 & 84 \\
\hline & & & No & 8 & 16 \\
\hline & & \multirow[t]{3}{*}{ Drama } & Yes & 21 & 42 \\
\hline & & & No & 29 & 58 \\
\hline & & & Yes & 24 & 48 \\
\hline & & Athletic & No & 26 & 52 \\
\hline & & \multirow{2}{*}{ Football } & Yes & 40 & 80 \\
\hline & & & No & 10 & 20 \\
\hline & & \multirow[t]{2}{*}{ Volleyball } & Yes & 44 & 88 \\
\hline & & & No & 6 & 12 \\
\hline & & \multirow[t]{2}{*}{ Debate } & Yes & 12 & 24 \\
\hline & & & No & 38 & 76 \\
\hline & & \multirow[t]{2}{*}{ Quiz } & Yes & 17 & 34 \\
\hline & & & No & 33 & 66 \\
\hline & & \multirow{2}{*}{$\begin{array}{l}\text { Extempore } \\
\text { Speech }\end{array}$} & Yes & 19 & 38 \\
\hline & & & No & 31 & 62 \\
\hline & & Essay & Yes & 15 & 30 \\
\hline & & Writing & No & 35 & 70 \\
\hline & & Poetry & Yes & 14 & 28 \\
\hline & & & No & 36 & 72 \\
\hline & & Recitations & Yes & 36 & 72 \\
\hline & & & No & 14 & 28 \\
\hline & & Singing & Yes & 34 & 68 \\
\hline & & & No & 16 & 32 \\
\hline
\end{tabular}

\begin{tabular}{|c|c|c|c|c|c|}
\hline & & \multirow[t]{2}{*}{ Dancing } & Yes & 42 & 84 \\
\hline & & & No & 8 & 16 \\
\hline & & \multirow{2}{*}{ Drama } & Yes & 18 & 36 \\
\hline & & & No & 32 & 64 \\
\hline \multirow[t]{3}{*}{3} & \multirow[t]{4}{*}{ CCA contributes physical fitness? } & KGBV & Yes & 50 & 100 \\
\hline & & & No & 0 & 0 \\
\hline & & GUPS & Yes & 44 & 88 \\
\hline & & & No & 6 & 12 \\
\hline \multirow[t]{4}{*}{4} & \multirow{4}{*}{$\begin{array}{l}\text { CAA contributes mental } \\
\text { development? }\end{array}$} & KGBV & Yes & 40 & 80 \\
\hline & & & No & 10 & 20 \\
\hline & & GUPS & Yes & 38 & 76 \\
\hline & & & No & 12 & 24 \\
\hline \multirow[t]{4}{*}{5} & \multirow{4}{*}{$\begin{array}{l}\text { CCA develops self confidence } \\
\text { among the students? }\end{array}$} & KGBV & Yes & 50 & 100 \\
\hline & & & No & 0 & 0 \\
\hline & & GUPS & Yes & 50 & 100 \\
\hline & & & No & 0 & 0 \\
\hline \multirow[t]{4}{*}{6} & \multirow[t]{4}{*}{ Do you think CCA is important? } & KGBV & Yes & 47 & 94 \\
\hline & & & No & 3 & 6 \\
\hline & & GUPS & Yes & 38 & 76 \\
\hline & & & No & 12 & 24 \\
\hline \multirow[t]{4}{*}{7} & \multirow{4}{*}{$\begin{array}{l}\text { Do you feel disturbed in your study } \\
\text { due to CCA? }\end{array}$} & KGBV & Yes & 14 & 28 \\
\hline & & & No & 36 & 72 \\
\hline & & GUPS & Yes & 10 & 20 \\
\hline & & & No & 40 & 80 \\
\hline \multirow[t]{4}{*}{8} & \multirow{4}{*}{$\begin{array}{l}\text { Do your school have separate } \\
\text { teachers for CCA? }\end{array}$} & KGBV & Yes & 13 & 26 \\
\hline & & & No & 37 & 74 \\
\hline & & GUPS & Yes & 10 & 20 \\
\hline & & & No & 40 & 80 \\
\hline \multirow[t]{4}{*}{9} & \multirow{4}{*}{$\begin{array}{l}\text { Do you have separate period for } \\
\text { CCA? }\end{array}$} & KGBV & Yes & 45 & 90 \\
\hline & & & No & 5 & 10 \\
\hline & & GUPS & Yes & 18 & 36 \\
\hline & & & No & 32 & 64 \\
\hline
\end{tabular}

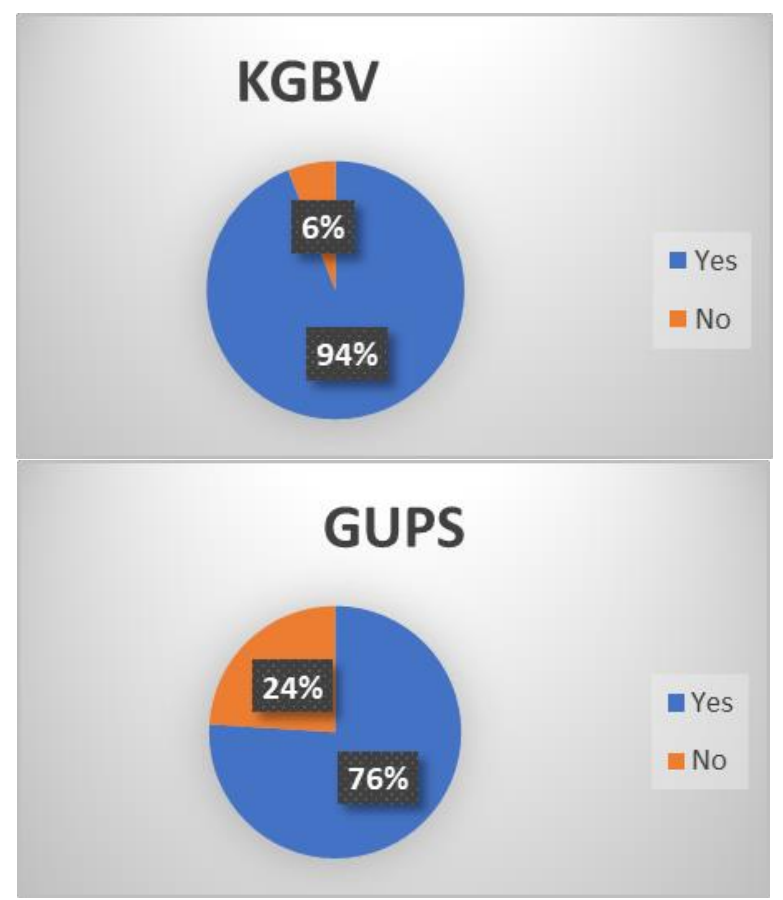

Fig. 1. Students responses on importance of CCA

From the Fig. 1, it is found $94 \%$ that is the majority of the girls' students of KGBV feels that CCA as important part of the curriculum. Only $6 \%$ feels that CCA is not important. In GUPS $76 \%$ responded Yes and 24\% responded No. Comparatively Yes on importance of CCA is more in KGBV than GUPS. 


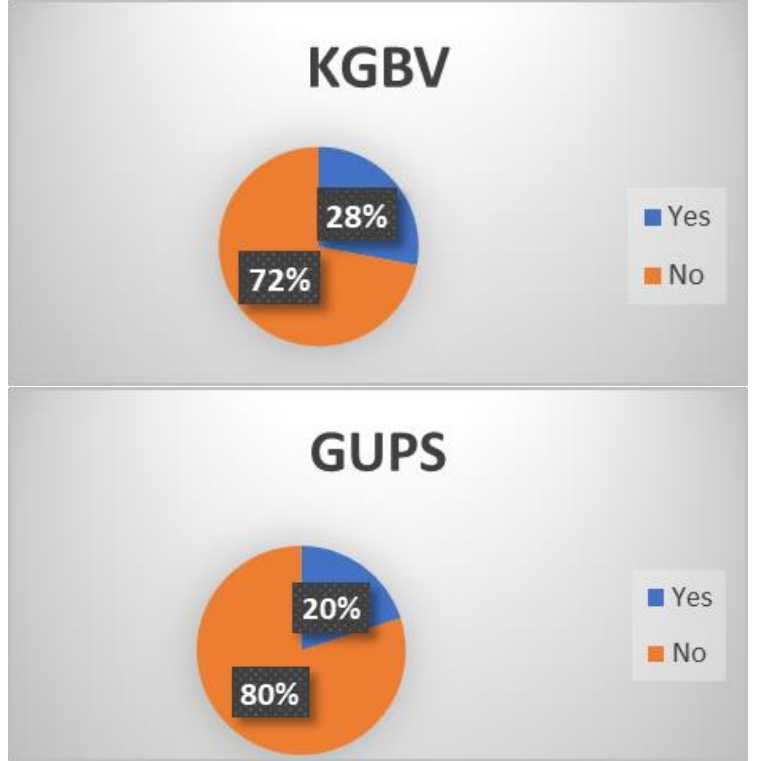

Fig. 2. The responses of girls' students of KGBV and GUPS on whether they feel disturbed in their study because of CCAs

From the fig. 3 it is revealed that $72 \%$ of girls' students of KGBV doesn't feel disturbed in their study because of CCAs and whereas it is $80 \%$ in GUPS.

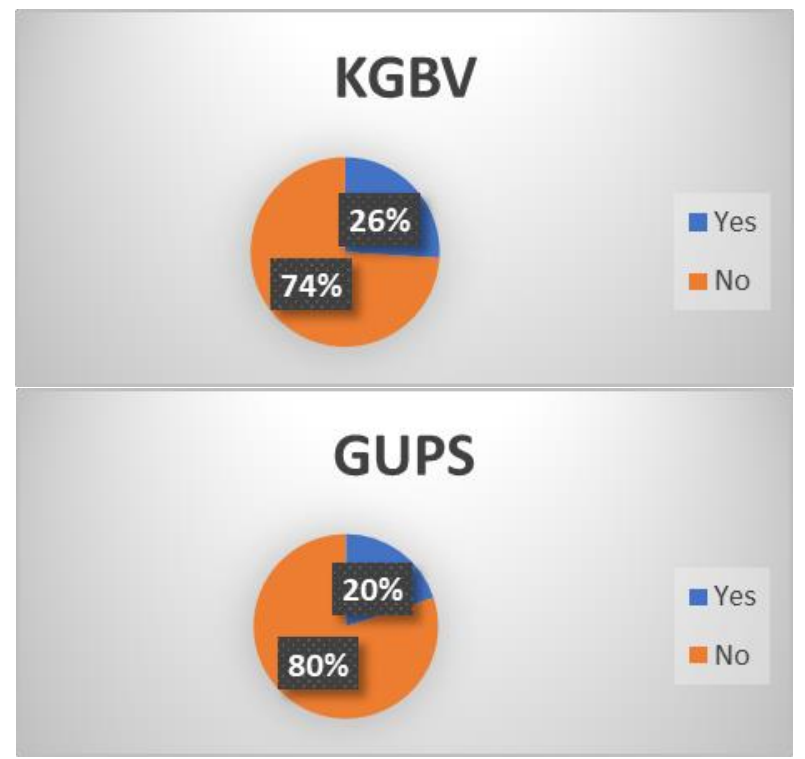

Fig. 3. Girls responses on availability of separate CCAs teachers in KGBV and GUPS of East Siang district

From fig. 3, it is found that $26 \%$ of girls' students of KGBV claimed to have the separate teachers for CCA in their school.74\% of government upper primary schools complained of not having separate teachers for CCA in their schools.
Table 3

Percentage of girls' participation in various Co-Curricular Activities of Kasturba Gandhi Balika Vidyalayas and Government Upper Primary Schools of East Siang

\begin{tabular}{|c|c|c|}
\hline $\begin{array}{l}\text { Co-curricular } \\
\text { Activities }\end{array}$ & Schools & $\begin{array}{c}\text { Percentage of girls' } \\
\text { participations }\end{array}$ \\
\hline \multirow{2}{*}{ Athletic } & KGBV & $76 \%$ \\
\hline & GUPS & $52 \%$ \\
\hline \multirow[t]{2}{*}{ Football } & KGBV & $60 \%$ \\
\hline & GUPS & $80 \%$ \\
\hline \multirow[t]{2}{*}{ Volleyball } & KGBV & $90 \%$ \\
\hline & GUPS & $88 \%$ \\
\hline \multirow[t]{2}{*}{ Debate } & KGBV & $36 \%$ \\
\hline & GUPS & $24 \%$ \\
\hline \multirow[t]{2}{*}{ Quiz } & KGBV & $56 \%$ \\
\hline & GUPS & $34 \%$ \\
\hline \multirow[t]{2}{*}{ Extempore Speech } & KGBV & $20 \%$ \\
\hline & GUPS & $83 \%$ \\
\hline \multirow[t]{2}{*}{ Essay Writing } & KGBV & $44 \%$ \\
\hline & GUPS & $30 \%$ \\
\hline \multirow[t]{2}{*}{ Poetry } & KGBV & $16 \%$ \\
\hline & GUPS & $28 \%$ \\
\hline \multirow[t]{2}{*}{ Recitations } & KGBV & $62 \%$ \\
\hline & GUPS & $72 \%$ \\
\hline \multirow[t]{2}{*}{ Singing } & KGBV & $72 \%$ \\
\hline & GUPS & $68 \%$ \\
\hline \multirow[t]{2}{*}{ Dancing } & KGBV & $84 \%$ \\
\hline & GUPS & $84 \%$ \\
\hline \multirow[t]{2}{*}{ Drama } & KGBV & $42 \%$ \\
\hline & GUPS & $36 \%$ \\
\hline
\end{tabular}

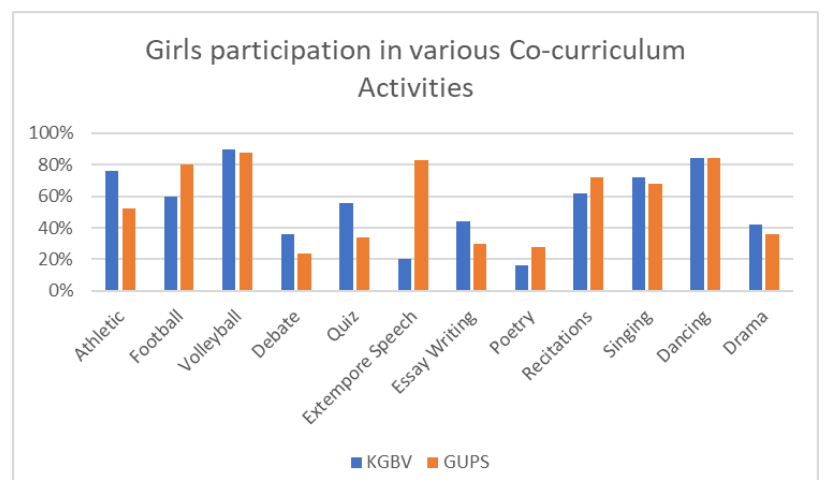

Fig. 4. Girls' participation in various Co-Curricular Activities of Kasturba Gandhi Balika Vidyalaya and Government Upper Primary Schools of East Siang district of Arunachal Pradesh

The fig. 4, shows that girls of Kasturba Gandhi Balika Vidyalayas participates in dancing, volleyball, recitations and singing activities. Whereas girls of Government Upper Primary Schools participate more in Volleyball, singing, football and dancing. Government Upper Primary Schools shows highest number of girls' participation in extempore speech than the girls of Kasturba Gandhi Balika Vidyalayas. Very few students took part in poetry and debate in both the type of school. However, it is found that Girls' of Kasturba Gandhi Balika Vidyalayas took more active participation in Co-Curricular Activities than Government Upper Primary School of Arunachal Pradesh.

\section{Results and Discussion}

The present study shows that the girls' participation is more 
in dancing, volleyball, singing and football. Very few girls participated in poetry, debate, quiz and athletics. The girls of both the school type are found to be more active in cultural activities and games. However, they found to be very poor in intellectual activities. For the overall development of the girl's student it is recommended that the Head teachers and teachers of the school need to motivates the girls for more participation in the various co-curricular activities. Providing proper rewards and incentives will encourage the girls to come forwards in different activities. Though co-curricular activities are nonacademics, in today's context, it becomes an integral part of the education process.

\section{Conclusion}

The present study on Co-Curricular Activities revealed that majority of the students are concerned about the importance of these activities. The survey conducted under National Federation of State High School Associations (1985), Ahmad M. et al. (2015), found that Co-Curricular Activities were valuable to the school experience. Daniyal et al. (2012) also supported that Co-Curricular activities affect academic achievements of the students and this impact depends upon the activities in which the students participated. Students and school's authority found to be felt as strongly about CoCurricular Activities. Therefore, the girl's students of both Kasturba Gandhi Balika Vidyalaya and Government Upper Primary School in East Siang districts need to be encouraged more regarding CCAs, by promoting an awareness programme on importance and benefits of Co-curricular activities.

\section{References}

[1] W. Bill, "Student Involvement in Co- Curricular Activities and Success on The Kansas Mathematics and Reading Assessments," Thesis, University of Missouri-Kansas, 2008.

[2] Daniyal, Nawaz, Hassan, and Mubeen, "The effect of Co-Curricular Activities on the Academic Performances of Students: A Case Study of the Islamia University of Bahawalpur, Pakistan," 2012.

[3] M. Ahmad, "Effect of Extra Curricular Activity on Student's Academic Performance," JAFMC Bangladesh, vol. 11, no. 2, December 2015. 